\title{
On-column cryofocusing and analyte enrichment device for gas chromatography systems
}

\author{
Audrius Sadaunykas*, \\ Audrius Zolumskis, \\ Audrius Markevičius, \\ Evaldas Naujalis \\ Metrology Department, \\ State Research Institute \\ Center for Physical Sciences \\ and Technology, \\ 231 Savanoriu Avenue, \\ 02300 Vilnius, Lithuania
}

\begin{abstract}
The objective of this work was to design, construct and test the sample focusing and concentration enrichment device for gas chromatography. The device was based on four metal rings, between which a capillary column and two wire heaters were placed. The metal rings were connected to each other and cooled down using liquid nitrogen. The column was connected to the gas chromatography system using a heated transfer line. The research was conducted on how the length of the cooled column influences focusing and enrichment capabilities of the system. It was found that the analytes were focused better by using a longer cooled part of the column. The longer cooled column was also able to retain a greater volume of the analytes, injected consecutively. By using the $95 \mathrm{~cm}$ cooled column length, it was possible to retain 20 injections and detect a 20 times bigger peak area. By changing the temperature of the cooling zone, it was also observed that peak symmetry is heavily dependent on it. Lower cooled zone temperatures produced narrower and more symmetrical peaks.
\end{abstract}

Keywords: gas chromatography, cryofocusing, analyte enrichment

\section{INTRODUCTION}

Gas chromatographic (GC) analysis requires adequate separation and sufficient analyte mass in the sample. Analyte separation is important to successfully detect or quantify specific compounds or avoid false measurement data. Separation largely depends on the GC column parameters and is also influenced by injector or carrier gas flow [1]. A minimum requirement of the analyte mass in the sample is determined by the signal to noise ratio $(\mathrm{S} / \mathrm{N})$ associated with the detector in use. It is widely considered that $\mathrm{S} / \mathrm{N}$ of $3: 1$ is the detection limit (LoD) of the method [2]. Sensitive detection and good separation are vital for the analysis of samples with a low concentration of analytes or difficult matrixes [3].

\footnotetext{
" Corresponding author. Email: audrius.sadaunykas@ftmc.lt
}

There are sample preparation methods that help to compensate for the lack of separation or sensitivity. Various extraction techniques [4] are being used to separate overlapping compounds in the chromatogram before analysis, or to extract a specific compound and concentrate it in a smaller amount of a solvent. Every additional sample preparation step costs money and time and may influence accuracy of the result, so it is best to find a way to avoid these steps.

Cryofocusing or cryotraping methods are little-known techniques, that are used rarely because of complicated instruments involved. These methods are based on cooling down the GC column, or its part to subambient temperatures. Analytes travelling along the column arrive at the cooled zone and are retained or significantly slowed down. Slowing down an analyte momentarily helps with separation, because it focuses an 
analyte on the column and reduces analyte spread, caused by the injection. Few consecutive injections into the GC system can be made to also concentrate the analyte on the column [5]. The cooled part of the column is heated rapidly after focusing or concentration to make analytes mobile again.

Cryofocusing devices are mostly based on three different designs: electrical cooling (Peltier element [6]) is the simplest method 诸, 8], but it is limited in its cooling capacity; cooled gas is more well-known and can be used to cool the whole GC oven or just part of the column [9]; a liquid gas system [10] can achieve very low temperatures in a short amount of time, but requires a liquid coolant $\left(\mathrm{He}\right.$ or $\left.\mathrm{N}_{2}\right)$. The cryofocusing device described in this paper is based on the liquid gas system.

\section{EXPERIMENTAL}

\section{Reagents and solutions}

Dichloromethane (solvent), octane (Sigma-Aldrich) (99\%), nonane (Sigma-Aldrich) (99\%) and decane (Sigma-Aldrich) (99\%) were used. A stock solution of these analytes was prepared in dichloromethane (10 ppm v/v).

\section{Instrumentation}

The chromatographic analysis was performed on a Perkin Elmer Autosystem XL gas chromatograph, equipped with an in-house cryofocusing and enrichment device and a flame ionization detector. Agilent DB-5MS, $0.2 \mathrm{~mm}$ ID, $30 \mathrm{~m}, 0.25 \mu \mathrm{m}$ phase thickness column was used.

\section{In-house made cryofocusing and enrichment device}

The analyte cryofocusing and enrichment device was built in-house. The device was based on four aluminum rings stacked onto each other (Fig. 1). The rings housed two nickelium chromium heating elements and a cavity, where the GC column will be inserted. The rings were situated in a heat isolating enclosure on top of the dewar with liquid nitrogen inside. The rings were connected to GC by a heated transfer line (Fig. 2). Liquid nitrogen was sprayed on the metal rings and the temperature was monitored using an external thermocouple. Heating and cooling were controlled using an external power supply and a controller.

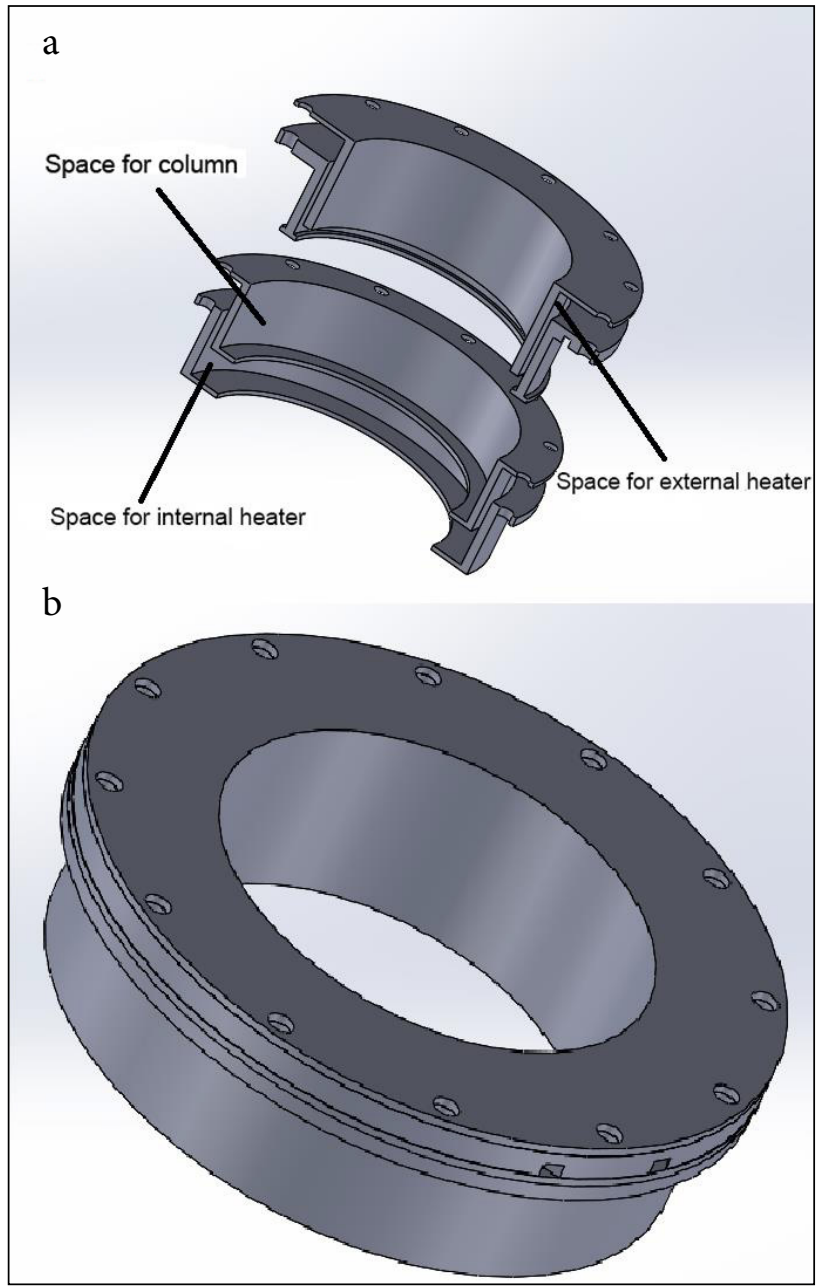

Fig. 1. Aluminum rings are designed to house the capillary column and heaters: (a) cross section of unfolded aluminum rings, (b) rings stacked on top of each other (coloured online)

This design was chosen, so it would be able to change the cooled column length easily. The column was winded in circles, until the desired length was reached. One circle of the column in the cryofocusing device is about $19 \mathrm{~cm}$ in length.

This paper is focused on providing a number of preliminary results and observations about a newly

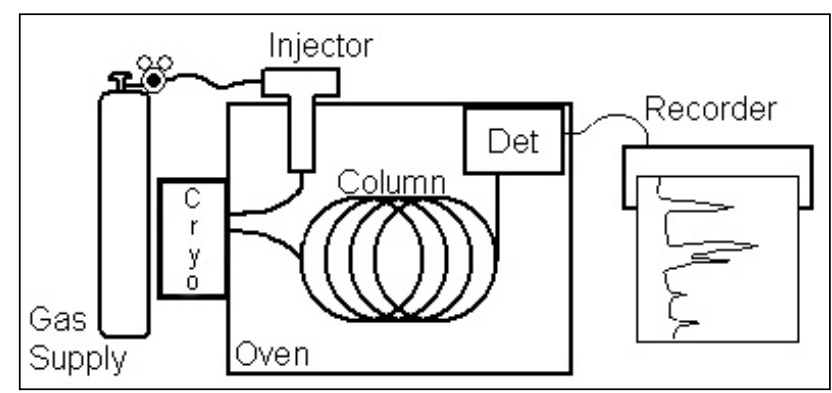

Fig. 2. Scheme of a prototype focusing and concentration system connected to a gas chromatograph 
described device. While there are many possible applications of this type of device, this paper will only focus on various cryofocusing and enrichment parameters that may influence chromatography peaks.

\section{RESULTS AND DISCUSSION}

\section{Focusing}

Focusing performance testing was performed by cooling down the cryofocusing device to $-60^{\circ} \mathrm{C}$ before the analysis and then injecting $(1 \mu \mathrm{l}, 1: 10$ split injection) an analyte mixture into a heated injector (temperature kept at $150^{\circ} \mathrm{C}$ ). The analyte mixture was propelled forward in the column by $1 \mathrm{ml} / \mathrm{min}$ flow of helium gas and was predicted to condensate and become stationary once it reached the cryofocusing device. After 2 min, the cryofocusing device was switched to the heating mode and rapidly $\left(\sim 3^{\circ} \mathrm{C} / \mathrm{min}\right)$ heated to around $120^{\circ} \mathrm{C}$. The vapourized analytes were made mobile again and moved along the column (oven temperature kept at $80^{\circ} \mathrm{C}$ ) towards the FID detector (temperature kept at $150^{\circ} \mathrm{C}$ ).

The results indicate that after focusing peaks were narrower and taller, increasing the efficiency of chromatographic separation. Also, solvent dichloromethane was not retained in the cryofocusing device (Fig. 3).

The influence of the cooled column length on focusing performance was evaluated by compar- ing the peak height after the analysis of the same mixture at different cooled column lengths. It was found that longer cooled column lengths produced taller and narrower peaks. The peak height increased up to 1.83 times for octane analyte and the heavier analyte focusing was less noticeable: 1.47 times for nonane and 1.27 times for decane.

\section{Enrichment}

Testing of the enrichment performance was performed similarly to the focusing performance test. The analyte mixture was injected number of times into the GC system with the cryofocusing device cooled to $-60^{\circ} \mathrm{C}$ and after 2 min the cryofocusing device was heated to $120^{\circ} \mathrm{C}$. It was predicted that the injected analytes would be retained in the cooled part of the column and after heating it up, their analyte area would increase corresponding to the number of injections made of the system.

First, the influence of the cooled column length on the number of injections retained was tested and it was found out that $95 \mathrm{~cm}$ of the cooled column at $-60^{\circ} \mathrm{C}$ could retain up to 20 injections and enrich the peak area up to 20 times (Table). Interestingly, peak asymmetry was prominent in the decane peak (Fig. 4). This could have been caused by sequential injections and heat they bring to the cooled part of the column. After each injection, the heat and solvent coming into the cryofocusing device push analytes along the column. More volatile analytes

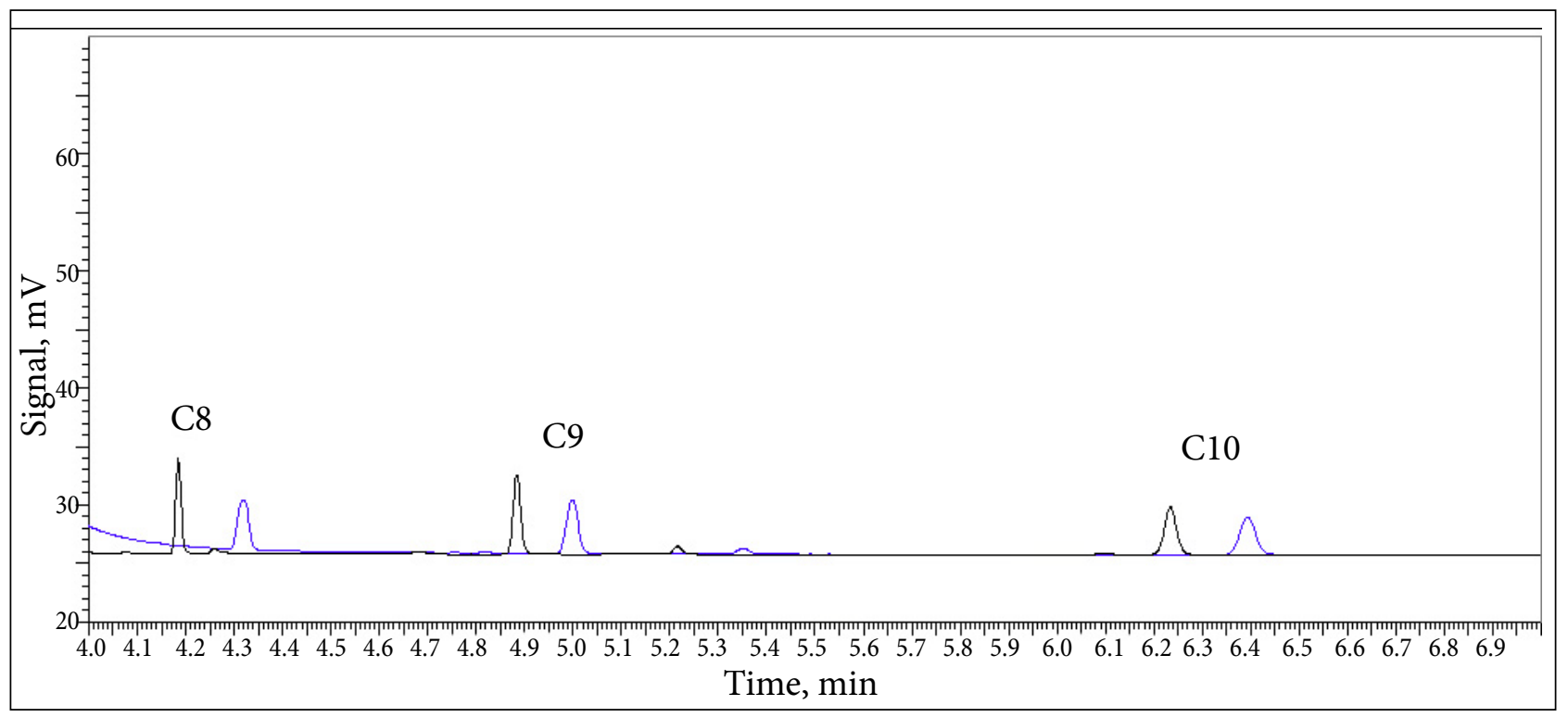

Fig. 3. Comparison of focused and unfocused chromatograms. Analytes: octane (C8), nonane (C9), decane (C10). Blue (online) for the analysis without focusing, black for the analysis with focusing 
Table. Results of the effect of the length of the cooled column part on the ability to retain analytes on the column

\begin{tabular}{|c|c|c|c|c|c|c|c|c|c|}
\hline \multirow{2}{*}{$\begin{array}{l}\text { Column } \\
\text { length, } \mathrm{cm}\end{array}$} & \multirow{2}{*}{ Analyte } & \multicolumn{8}{|c|}{ Enriched analyte peak area divided by non-enriched peak area } \\
\hline & & 2 & 3 & 5 & 7 & 10 & 15 & 20 & 25 \\
\hline \multirow{3}{*}{19} & $\mathrm{C} 8$ & 1.79 & 2.33 & 2.30 & - & - & - & - & - \\
\hline & C9 & 1.69 & 2.40 & 2.24 & - & - & - & - & - \\
\hline & C10 & 1.66 & 2.22 & 3.44 & - & - & - & - & - \\
\hline \multirow{3}{*}{39} & $\mathrm{C} 8$ & - & 3.10 & 4.75 & - & - & - & - & - \\
\hline & $\mathrm{C} 9$ & - & 3.07 & 4.88 & - & - & - & - & - \\
\hline & $\mathrm{C} 10$ & - & 3.12 & 4.91 & - & - & - & - & - \\
\hline \multirow{3}{*}{57} & C8 & - & 2.47 & 3.99 & 5.73 & - & - & - & - \\
\hline & $\mathrm{C} 9$ & - & 3.12 & 4.91 & 7.07 & - & - & - & - \\
\hline & C10 & - & 3.14 & 4.97 & 7.15 & - & - & - & - \\
\hline \multirow{3}{*}{76} & C8 & - & 2.67 & 4.55 & 6.99 & 8.45 & 14.67 & 16.05 & - \\
\hline & $\mathrm{C} 9$ & - & 3.11 & 5.47 & 7.20 & 10.11 & 15.14 & 16.19 & - \\
\hline & C10 & - & 3.14 & 5.57 & 7.36 & 10.41 & 15.45 & 15.90 & - \\
\hline \multirow{3}{*}{95} & C8 & - & 2.82 & 4.32 & 5.94 & 8.43 & 15.51 & 19.75 & 19.71 \\
\hline & $\mathrm{C} 9$ & - & 3.22 & 5.29 & 7.30 & 10.34 & 15.57 & 20.67 & 22.25 \\
\hline & C10 & - & 3.27 & 5.36 & 7.39 & 10.37 & 15.53 & 20.71 & 22.40 \\
\hline
\end{tabular}

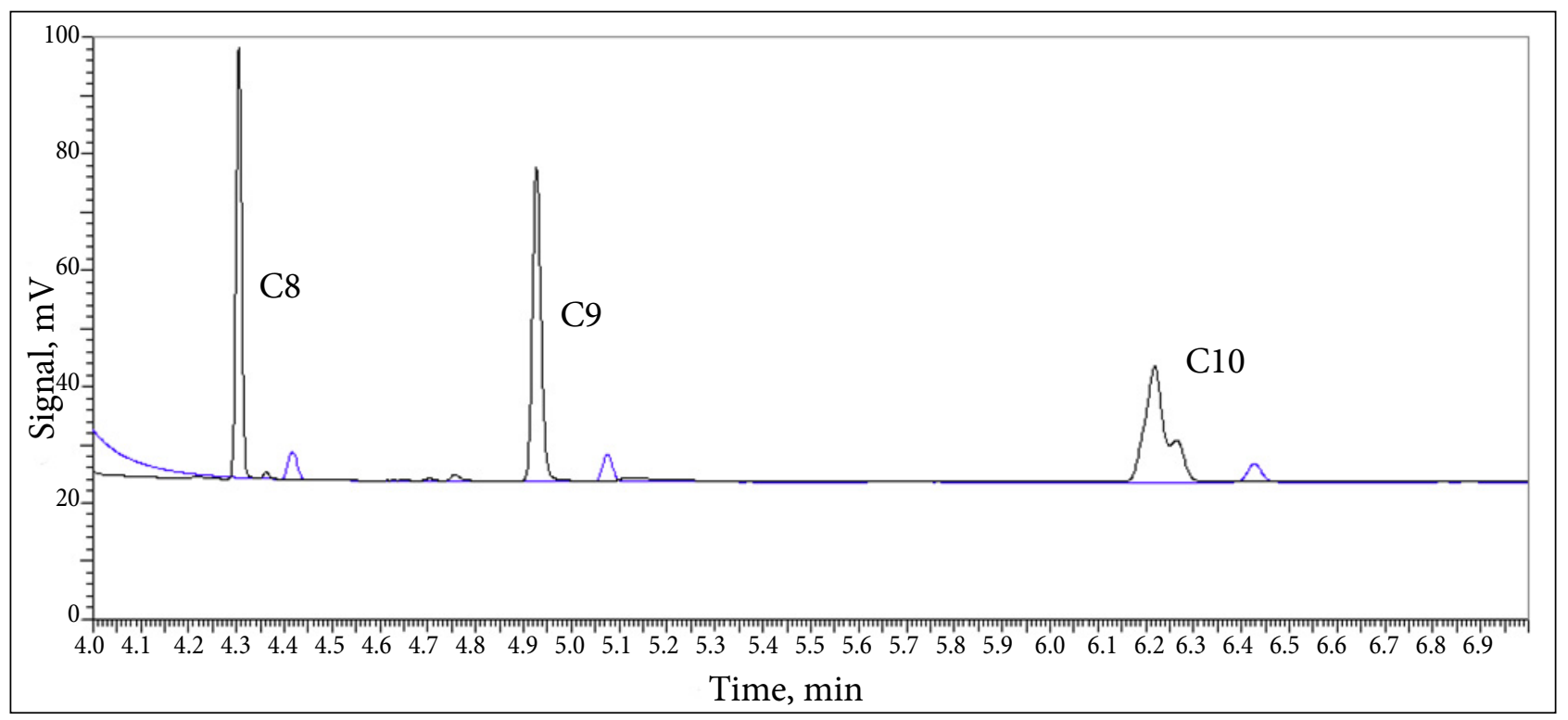

Fig. 4. Comparison of chromatograms of 10-times concentrated (black) and non-concentrated (blue) chromatograms (coloured online). AnaIytes: octane (C8), nonane (C9) and decane (C10)

are moved by it forward and less volatile analytes are less prone to be moved. Decane, which is less volatile, is not moved uniformly and create separate concentrated areas on the column and after heating up the cryofocusing device, the split peak reenters the GC system.

The temperature influence on enrichment performance was found to be important for the peak shape and its width. At -30 and $-45^{\circ} \mathrm{C}$ nonane dis- played asymmetry, while decane was asymmetric up to $-90^{\circ} \mathrm{C}$, but the decrease in temperature made the decane peak narrower and more symmetric (Fig. 5). Peak asymmetry could be contributed to the same heat entering the cryofocusing device effect discussed before. Also, it is worth noting that dichloromethane is starting to be retained at $-60^{\circ} \mathrm{C}$ and its retention increases when lowering the temperature. 


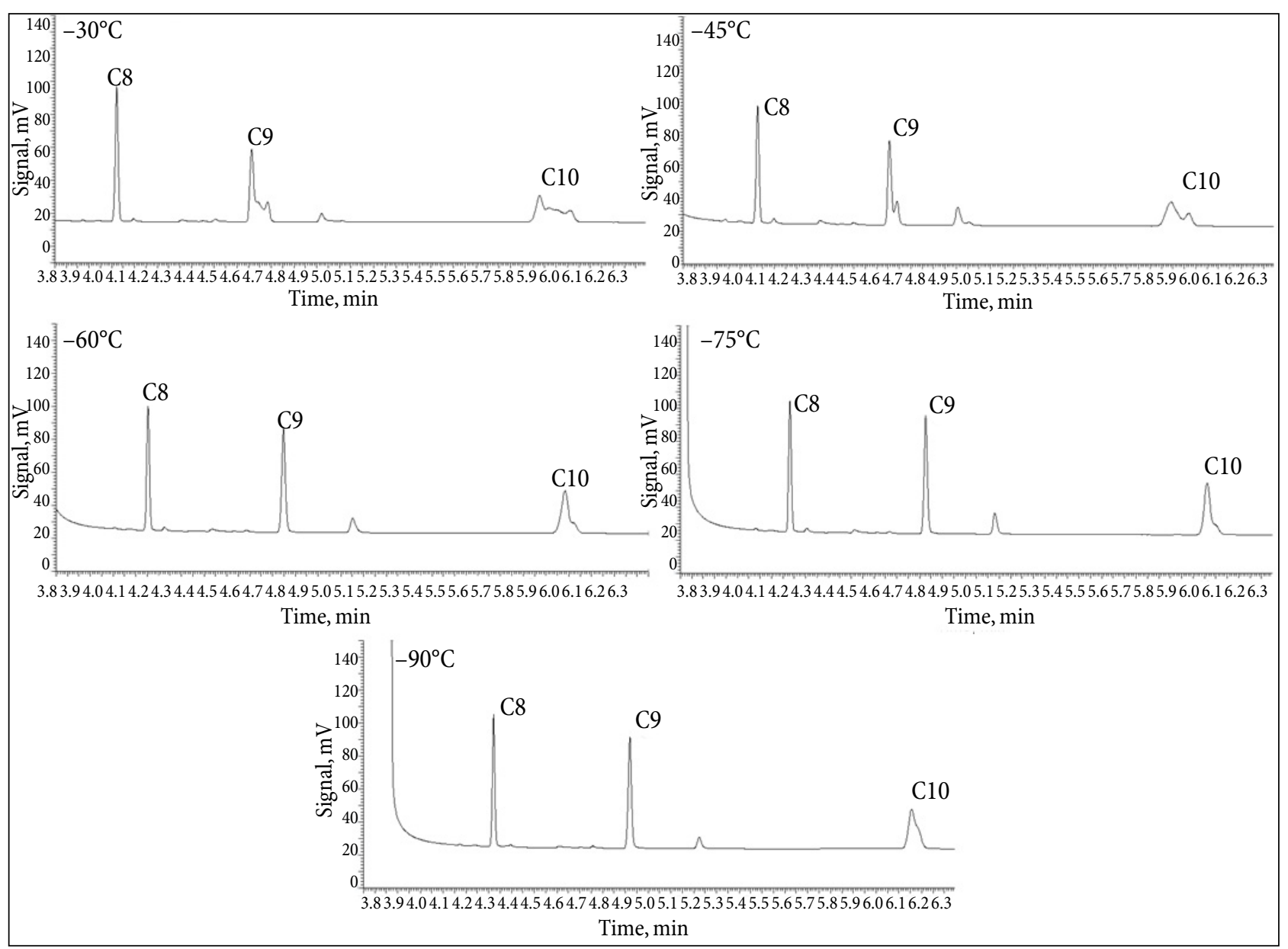

Fig. 5. The temperature dependence of the peak shape in the cooled zone of the column. Analytes: octane (C8), nonane (C9), decane (C10)

\section{CONCLUSIONS}

The in-house designed analyte focusing and enrichment device for GC systems shows a big potential. Analytes could be focused up to 1.83 times and enriched up to 20 times. That allows one to measure samples with a lower concentration of the analytes and separate similar compounds more effectively. Still, there are problems with peak asymmetry and repeatability of the system was not tested during the course of this work, which leaves some concerns about the use of this type of system in routine work. Further work should be directed towards minimizing the peak asymmetry and the testing system using it in quantitative analysis.

\section{References}

1. K. Grob, G. Grob, K. Grob, J. Chromatogr. A, 156, 1 (1978).

2. E. Bernal, in: X. Guo (ed.), Advances in Gas Chromatography, IntechOpen (2014).

3. T. Gunnar, S. Mykkänen, K. Ariniemi, P. Lillsunde, J. Chromatogr. B Analyt. Technol. Biomed. Life Sci., 806(2), 205 (2004).

4. S. Lee, N. Kim, D. Lee, Anal. Bioanal. Chem., 377, 749 (2003).

5. S.-T. Chin, B. Maikhunthod, P. J. Marriott, Anal. Chem., 83(17), 6485 (2012).

6. Peltier Effect [https://www.britannica.com/science/ Peltier-effect].

7. M. Libardoni, J. H. Waite, R. Sacks, Anal. Chem., 77(9), 2786 (2005).

8. T. Górecki, J. Harynuk, O. Panić, J. Sep. Sci., 27(56), 359 (2004).

9. V. Cocheo, C. Boaretto, F. Quaglio, P. Sacco, R. Zannetti, The Analyst, 116(12), 1337 (1991).

10. R. B. Wilson, B. D. Fitz, B. C. Mannion, et al., Talanta, 97, 9 (2012). 
Audrius Sadaunykas, Audrius Zolumskis,

Audrius Markevičius, Evaldas Naujalis

KRIOFOKUSAVIMO IR ANALIČIŲ

KONCENTRAVIMO ANT KOLONE்LE்S

IRENGINYS, SKIRTAS DUJU

CHROMATOGRAFINEI SISTEMAI

Santrauka

Darbo tikslas buvo suprojektuoti, sukonstruoti ir išbandyti mèginių fokusavimo ir koncentracijos papildymo prietaisą dujų chromatografijai. Prietaisą sudare keturi metaliniai žiedai, tarp kurių buvo įdèta kapiliarinè kolonèlè ir du vieliniai šildytuvai. Metaliniai žiedai buvo sujungti vienas su kitu ir atvésinti naudojant skystą azotą. Kolonèle buvo prijungta prie dujų chromatografijos sistemos naudojant šildomą perdavimo liniją. Tirta, kokią itaką šaldomos kolonos ilgis daro sistemos fokusavimo ir papildymo galimybėms. Nustatyta, kad analitès buvo geriau sufokusuotos naudojant ilgesnę šaldomos kolonèlès dalị. Ilgesnè šaldoma kolonèlè taip pat sugebéjo sukaupti didesni analizuojamų analičiu kiekį. Naudojant $95 \mathrm{~cm}$ ilgio aušinamą kolonèlę buvo galima išlaikyti iki 20 injekcijų ir aptikti 20 kartų didesnị smailès plotą. Keičiant aušinimo zonos temperatūrą pastebèta didelè ịtaka smailių simetrijai. Naudojant žemesnę aušinamos zonos temperatūrą gaunamos siauresnès ir labiau simetriškos smailès. 